\title{
The Integration of Native Language in EFL Classes
}

\author{
Heriberto González Valencia ${ }^{1}$ \\ ${ }^{1}$ Institución Universitaria Escuela Nacional del Deporte, Cali, Valle, Colombia \\ Correspondence: Heriberto González Valencia, Sports Faculty (END), Cali, Valle, Colombia.
}

Received: August 5, 2018

Accepted: December 2, 2018 Online Published: December 6, 2018

doi: $10.5539 /$ elt.v12n1p1

URL: https://doi.org/10.5539/elt.v12n1p1

\begin{abstract}
This article shows how the integration of native language in EFL classes affect positively the teaching and learning processes of English as a foreign language. The methodology shows a quantitative approach performing different processes and techniques adapted to the requirements of the investigation, data is the result of tests done to two groups of fifteen students in two class at a university, surveys and interviews. There is a theoretical research from authors about the use of native language in EFL classes which makes the investigation very solid. The results show that the integration of students' native language in the learning of English as a foreign language can help them achieve their learning goals.
\end{abstract}

Keywords: native language, EFL, English, teaching and learning process

\section{Introduction}

English is understood as the universal language and many people for different reasons need, must or want to learn it as a foreign language. González (2015) stated that English is a medium of instruction in many countries and is the connecting language of the world market. This author also mentioned that it is a priority in Colombian education to reach an optimum level in English for a good performance in different areas of occupation, (González 2015). It is also a requirement in the curricula of many educational institutions, due to its global importance. On the other hand, students of higher education have understood the importance of handling a foreing language to be able to obtain a good job.

Through the ages many approaches and methods have been implemented with the idea of improving the teaching and learning processes of English as a foreign language and the needs for which English is studied change through the time.

The use of the native language can become an ally and motivation for many students. Martín (2001) wrote that the native language can play a facilitating role in the different learning processes of a new language. This can be seen from a negative and a positive side; the use of the native language allows some students to assimilate a foreign language more easily. On the other hand, one might think that students enter the phase of ease and laziness when the professor speaks to them in their native language they do not need to strive for the acquisition of the language they are studying.

The quality of the teaching process will always be linked to transformation, (Valencia, Enriquez, \& Acosta, 2018). In this process the professor plays a very important role, his/her performance in class can determine and affect the development of the students in class. The motivation that they can have in improving their labor and socio-cultural expectations with the acquisition of this language. The institution where this research was conducted has all the resources for teaching English as a foreign language. Very well qualified professors, facilities, all the necessary equipment and a very good physical structure.

Students who study at the institution have generally had some contact with the language, which could be seen as something positive in the learning process that they start at university. But on the other hand, one could say that the level they have received is very low, and that in their high school English classes the language under study was not used very frequently. According to Sánchez (2012) English levels in Colombia are quite low.

\section{Native Language in the Teaching of a Foreign Language}

Currently, English is the most common foreign language in the world. The purposes for which English language is used create the need to implement strategies to optimize its learning. As good educators, the need to create strategies that allow the learner to improve the teaching-learning process is visualized. As Valencia, Enriquez and 
Agredo (2017) stated, the strategy is an integral concept in the field of education.

Many English professors in Colombia wonder if the use or non-use of the native language in English classes benefits or not. Understanding by native language, the first language a person learns. In general the issue of the use of the native language by the professors is not a matter of easy discussion among them since in many cases they think that it is not admitted.

Different studies have provided information about the use of the native language in the acquisition of English as a foreign language. For example, Widdowson (1979) stated:

“... Language students should be aware of what they are doing when they perform linguistic tasks. They should be guided to recognize that these tasks are related to the way they use their own language for the achievement of genuine communication. This principle naturally leads to the association of the language that is learned with that which is already known and to the use of the language for the exploration and extension of their knowledge". (Widdowson, 1979)

Hearn and Garcés (2003) said that the professor use to speak the native language on top of the foreign language, since he/she used to explain and address the students in their native language and not in the language being studied and the books showed grammar in the same way. This teaching model deprived students of a long time of exposure to the foreign language, the first and essential element in the process of acquiring a foreign language.

On the other hand, different authors mention that the use of the native language can be forced in case of physical or emotional security of the student at risk or in disciplinary matters. The use of the native language was also justified when it comes to transmit explanations, expressions or very abstract or complex words and when other strategies become unfruitful.

According to Kavaliauskiene (2009), it is very important to distinguish between teaching using translation as a vocational skill and the use of the native language in a teaching situation as an aid in the learning of a language. We must also take into account concepts such as interlanguage; in the learning of a foreign language, the speaker will produce a linguistic system of transition called interlanguage which is a system that results from the combination of his/her native language with the foreign language he/she learns.

Many have presented the use of the native language in an English class as support, the amount of its use depends largely on the academic level of the students. It can also lead to a cultural approach to the language under study, but it can lead to a delay in the communication of students in the foreign language. The teaching of English through English is still the main idea, although discrimination against the use of the native language can be very stressful for many learners.

Del Rio (1996) suggested that the student's native language can be a valuable contribution to the foreign language in the classroom. Krashen and Terrell (1983), mentioned that students must use their native language to fill gaps in communication due to their insufficiency to initiate interlanguage statements. O'Malley and Chamot (1990) in their work of academic cognitive approach to language learning, which is based in part on their research on learning strategies, also demonstrated that the native language can be used as a useful learning aid. Corder (1981) seemed to agree on what he considers the use of the native language as a "heuristic technique" that results from the students' strategies to master the language.

Rutherford (1987), another defender of the native language, argueed that, when trying to learn a foreign language, the student is equipped with two types of prior knowledge, the knowledge labels and the knowledge that form it. The first is, as he said:

"An unconscious 'knowledge' or innate 'idea' of what constitutes the organization that the language can assume. This ability is in the student's disposition and is activated every time the student has to deduce the unknown in the language on the basis of their rudimentary interlanguage and secondly, the technical knowledge, the mirrors of the mother tongue, their learning experience: temporarily the ability to bend the new language in ways that, with the maximum efficiency, serving the initial will of rudimentary communication." (Rutherford, 1987).

Texidor (2007) wrote that the use of the native language in the teaching of a foreign language has been a point of discussion since the emergence of the methodology of language teaching. Bolitho (1983) stated that in some moments of language teaching one has to allow the students to say what they want to say, and if they are going to do that, one is going to have to allow them to use their native language on some occasions. The native language brings benefits for the student (Ur, 2000). Clark (1975) pointed out that the native language can be very useful.

Although Atkinson (1983) suggested the limited and careful use of the native language in foreign language classes, he also suggests that it can be used for translation as a technique in teaching, and in relation to this 
Widdowson (1979) stated that the translation conceived in a certain way, can be a very useful pedagogical tool, and in some circumstances, can be seen as a service tool. Schweers (1999) stated that English must be the first vehicle of communication in the environment of teaching this language.

\section{Metodology}

The following is a quantitative research, since it is based on data which is intended to verify ideas obtained with quantitative techniques such as surveys and experimental tests with pre-post exams.

In this research surveys were obtained form students and professors of a university's language institute, where students were asked their opinion about the use of the native language by the professor (Spanish) in their English classes and how beneficial they believe it can be for their teaching and learning process.

They also asked the professors of the institute about the use of the native language (Spanish) by them in their English classes. Additionally, some directors from other institutes were interviewed.

A pre-test and a post-test were done to two (2) groups of students in A2 English level, selecting 15 students at random in each of the groups. The first exam was done before the professor explained the first four units, one of the professors did not use the native language, while the other one gave some instructions in the native language. After the professors explained the two units referring to the exam subjects, the same students were given the test again.

Based on this, an analysis and a description of the data was carried out, taking into account the characteristics of the participants and their interests, trying to establish in what degree the use of the native language affects or benefits in the teaching and learning process of a foreign language. The theory was related to these analyzes in order to make conclusions about the subject.

\section{Results}

For the following description, we will name one of the professors, professor A (who did not use the native language in his class) and the other one, professor B (who used the native language in his class). The groups studied a weekly three hours English class. For a period of five weeks, the professor's B group was given instructions and the grammar was explained in their native language, while professor's A explained only in the foreign language.

Class in both groups began with the introduction of a new topic in English. After giving the introduction and having presented the new topic, they continued to do evaluation exercises to identify their shortcomings. After having done the written and oral exercises; Failures in the subject were identified. To be sure of the appreciations professor B asked question in Spanish about who was not clear on the subject. At that time some students raised their hands and then proceeded to explain in the native language for a maximum period of 10 minutes. Once the clarifications were made, the class continued in English. While Professor A addressed the same question in English.

The following graphs show the results of the groups before and after the test, where the results have a very small margin of difference.

Table 1. Average score of the exams in a scale of 0.0 to 5.0 pretest and posttest of group A with 15 selected students

\begin{tabular}{ll}
\hline Students with average below 3.0 in the pretest. & Students with average below 3.0 in the posttest. \\
\hline $93 \%$ & $60 \%$ \\
Students with an average of 3.0 or more in the pretest. & Students with average of 3.0 or more in the posttest. \\
$7 \%$ & $40 \%$
\end{tabular}

Source: Heriberto Gonzalez Valencia. 
Table 2. Average score of the exams in a scale of 0.0 to 5.0 pretest and posttest of group B with 15 selected students

\begin{tabular}{ll}
\hline Students with average below 3.0 in the pretest. & Students with average below 3.0 in the posttest. \\
\hline $100 \%$ & $53 \%$ \\
Students with an average of 3.0 or more in the pretest. & Students with average of 3.0 or more in the posttest. \\
$0 \%$ & $47 \%$
\end{tabular}

Source: Heriberto Gonzalez Valencia.

According to the different theories mentioned in this research, where it is noted that the use of the native language can be a tool in the teaching and learning process of a foreign language, we see that the difference of the use or not of this, does not showed a result with significant differences, we see how the professor's B group, who used the native language, did not get a significant difference in the test campared to the group of the professor A who did not use the native language in his class. It must also be taken into account factors such as the disposition of students at the time of the test, since that gives a small margin of alteration in the test.

The results of the questionnaire for the students showed that in $90 \%$ of the cases, they agree with the use of the native language in English class as a foreign language. And they also felt the need to use their native language to express their needs and doubts in the classroom.

Table 3. Questionnari for students

\begin{tabular}{ll}
\hline Agree to the use of native language in class. & Do not agree to the use of native language in class. \\
\hline $90 \%$ & $10 \%$ \\
\hline
\end{tabular}

Source: Heriberto Gonzalez Valencia.

In the questionnaire for professors, $80 \%$ of them answered that they used the native language as an academic strategy for teaching English, but all of them made different clarifications regarding the time and manner they use it.

Table 4. Questionnari for professors

\begin{tabular}{ll}
\hline Use of native language in class. & Do not use of native language in class. \\
\hline $80 \%$ & $20 \%$ \\
\hline
\end{tabular}

Source: Heriberto Gonzalez Valencia.

In several open talks with professors of the institution about the subject, many agreed on the use of the native language as a pedagogical strategy in their English classes, to explain grammatical clarifications in which the concepts have not been clear to students; to give very important instructions in which there can be no errors; when there are problems both academic and behavioral.

In interviews with two directors from different institutions in the region, it was found that the use of the native language is not part of the academic strategy, however they claimed to know of some professors who use it at certain times of their classes.

In our environment, the use of the native language in English class does not stop being something that is not spoken very openly, many professors still think that admitting they use their native language as an academic instrument in the class can be seen as wrong. This is why in the surveys each professor explained his reasons for using it in his classes and all agreed that the use was very little.

\section{Conclusions}

According to everything compiled in the theoretical part of this work and with the results obtained in the pretest and posttest done to students, it was observed that although there is no significant difference, the proper use of the native language English class as a foreign language can be beneficial, since it can facilitate the learning process of 
students.

On the other hand, it should be mentioned that although it is not possible to give an exact measurement, as to how much time or quantity of the use of the native language should be implemented, if it can be assured that it is not the purpose of this research to support the idea of a translation method in class, since this worsens the possibilities of the students of being in contact with the language in study most of the time and reduces their possibilities of practices.

The English professor must be recognized as such, and for this purpose nothing better than the constant use of English in all spaces. However, taking into account the specific characteristics of many students in the university, there are very specific situations and needs in which the use of the native language in the teaching and learning process of English as a foreign language can be decisive for the optimal performance of students and also for them to continue with a high motivation in a long-term learning process such as learning a foreign language.

\section{Referencias}

Atkinson, D. (1983). Teaching monolingual classes. London: Longman Group United Kingdom.

Bolitho, R., Gower, R., Johnson, K., Murison-Bowie, S., Rossner, R., \& White, R. (1983). Talking shop: The communicative teaching of English in non-English-speaking countries. ELT Journal, 37(3), 235-242. https://doi.org/10.1093/elt/37.3.235

Clark, R. (1975). Adult theories, child strategies and their implications for the language teacher, In J. P. B. Allen, \& S. Pit Corder (Eds.), The Edinburgh Course in Applied Linguistics (Vol. 2., pp. 291-342). London: Oxford University Press.

Corder, S. P. (1981). Error analysis and interlanguage. Oxford: Oxford University Press.

Del Río, M. J., \& Sánchez Cano, M. (1996) Psicopedagogía de la Segunda Lengua. En Escoriza Nieto, J. Psicología de la Instrucción. Barcelona. EUB.

González, H. (2015). La integración de la tecnología como herramienta significativa en la enseñanza del inglés como lengua extranjera. Revista Horizontes Pedagógicos, 17(1), 53-66.

Hearn, I. y \& Garcés Rodríguez, A. (2003). Didáctica del Inglés para primaria. PEARSON EDUCATION, Madrid.

Kavaliauskiene, G. (2009). Role of mother tongue in learning English for specific purposes. Mykolas Romeris University, Vilnius, Lithuania

Krashen, S., \& Terrell, T. D. (1983). The Natural Approach. Pergamon.

Martín Martín, J. M. (2001). Nuevas tendencias en el uso de la L1. Universidad Pablo de Olavide, Sevilla

Ministerio de Educación Nacional de Colombia. (1999). Lineamientos curriculares, idiomas extranjeros. Editorial magisterio.

O'Malley, J. M., \& Chamot, A. U. (1990). Learning Strategies in Second Language Acquisition. Cambridge: Cambridge University Press. https://doi.org/10.1017/CBO9781139524490

Rutherford, W. E. (1987). Second language grammar: Learning and teaching. Longman.

Sánchez, A. (2012). El bilingüismo en los bachilleres colombianos. Documentos de Trabajo Sobre Economía Regional, No. 159, Banco de la Republica.

Schweers, W. (1999). Using L1 in the L2 classroom. Forum.

Texidor, R. (2007) El uso de la lengua materna en la enseñanza de idiomas extranjeros. La Habana, Cuba.

Ur, P. (2000). The communicative approach revisited. Newsletter.

Valencia, H. G., Enriquez, J. A. V., \& Agredo, P. M. (2017). Strategies Used by Professors through Virtual Educational Platforms in Face-To-Face Classes: A View from the Chamilo Platform. English Language Teaching, 10(8), 1. https://doi.org/10.5539/elt.v10n8p1

Valencia, H. G., Enriquez, J. A. V., \& Acosta, L. R. (2018). The Education of an English Professor: The Biographical Narrative. English Language Teaching, 11(4), 101. https://doi.org/10.5539/elt.v11n4p101

Widdowson, H. G. (1979). Teaching language as communication. Oxford University Press. UK. 


\section{Copyrights}

Copyright for this article is retained by the author(s), with first publication rights granted to the journal.

This is an open-access article distributed under the terms and conditions of the Creative Commons Attribution license (http://creativecommons.org/licenses/by/4.0/). 